\title{
Another bill bites the dust
}

THE medical research councils of nine European countries have agreed on a policy about in vitro fertilization (IVF). Recognizing the need for "informed public debate", the councils last week sent British Members of Parliament (MPs) copies of a statement detailing their conclusions. The statement reached MPs in time for a proposed debate in the House of Commons in which $\mathrm{Mr}$ Ken Hargreaves was reintroducing a bill to ban the creation or use of human embryos except for "enabling a child to be borne by a specified woman", a re-run of Mr Enoch Powell's bill which did not succeed in the last parliamentary session. In the event, the bill was not debated because of lack of time; it is unlikely to be revived.

The nine research councils (Denmark, Finland, West Germany, Italy, Sweden, the Netherlands, United Kingdom, Austria and Belgium) agree that IVF research should be restricted to the "preembryo", the collection of dividing cells before the appearance of the primitive streak, and should have the aims only of reducing infertility, of reducing congenital and hereditary disorders and of the development of safer contraceptive methods. Cloning of pre-embryos, manipulation of the genome to alter characteristics, growing pre-embryos beyond 14 days and the production of hybrids are all banned. Each country is urged to set up an ethical committee "to advise doctors and scientists and to inform and reassure the public". The committee should also contain "substantial lay membership".

The British Medical Research Council has given a $£ 400,000$ grant to the University of Edinburgh for IVF research. The programme will first develop a test to identify accurately healthy pre-embryos. The identification of gross embryo abnormalities in the laboratory will lead to a better chance of live births from replaced embryos, fewer multiple births and reduction in the risk of genetic disease, according to Professor David Baird, leader of the project.

Maxine Clarke

\section{Academic redundancies}

\section{Committee retires in confusion}

A House of Commons inquiry into the circumstances under which British academics have been prematurely pensioned off collapsed last week when it seemed to the committee concerned, the powerful Public Accounts Committee, that the National Audit Office (NAO) and the Department of Education and Science (DES) could not agree about the consequences of the rapid contraction of the university system begun in 1981 .

The committee had met to consider a report on the contraction of the British university system prepared by NAO which dealt with the question whether the cost of retiring academics early, estimated at $£ 238$ million, had been a sensible use of public money. The report (HC 598) is still available from Her Majesty's Stationery Office at $£ 2.80$ even though the Public Accounts Committee, on the showing of last week, plainly considers it valueless.

The committee first looked into the effects of government policy towards the universities before the first cuts took effect in August 1981, and was then told that some 3,000 academics and 4,000 nonacademic people would have to leave the universities. In the event, by September 1984 , a total of 4,400 academics, but only 2,800 non-academics, had left. In retrospect, NAO estimates that the extra cost of the compensation paid to those leaving early consists of $£ 153$ million paid directly by the University Grants Committee together with an estimated $£ 85$ million universities will have to contribute towards pensions schemes (out of their recurrent grants) in the years ahead.

Last week's fiasco seems to have arisen because the permanent secretary at DES, Sir David Hancock, drew into the discussion matters outside the period covered by the NAO review, which was exclusively concerned with the redundancy of university staff members up to September 1984. Thus he drew attention, for example, to the scheme for the appointment of "new blood" lectureships at the universities, offering this as one of the ways in which DES had helped to undo some of the damage done in the universities.

This is where the parliamentary system comes up against a brick wall. It is accepted that civil servants cannot criticize the policies of the governments for which they work, but if unpleasant things occur as a result of those policies, when does the cataloguing of those events add up to criticism?

The result, last week, was that the parliamentary committee became too confused to carry on. Believing that NAO and DES were somehow in disagreement, it sent them away with instructions to produce an agreed report. But DES said earlier this week that the existing document had been agreed between the two parties. Could last week's abortive committee hearing have been a clever ploy to postpone discussion of an embarrassing report?
US research grants Experiment in
informality

\section{Washington}

A UNIQUE experiment intended to cut down the time spent by researchers on tedious form-filling is due to start next month in Florida. Officials of five federal agencies have agreed that, for the next two years, they will use a single simplified form of research grant in the hope of reducing the administrative burdens of most principal investigators.

The Florida Demonstration Project arose out of discussions organized last summer by the National Academy of Sciences' government/university/industry research roundtable. In contrast with many similar past discussions, this led directly to a decision by officials to devise a test of how proposed improvements might work. Remarkably, the scheme has been set in place in just eight months.

The basic problem, the group agreed, is that existing federal accounting procedures tend to work best for projects with specific goals, rather than for research, which is by its nature unpredictable. Futhermore, as things are, accounting procedures are often duplicated at institutional and state levels. The end result, for the principal investigator, is that there are several forms to fill in, while Washington must be consulted in writing whenever funds allocated for foreign travel are used for buying a new piece of laboratory equipment, for example.

The new standard grant removes many of the cumbersome restrictions on normal grants, leaving the institution to which a grant is made responsible for accountability. Explicit prior approval would, for example, no longer be necessary should an institution choose to risk spending grant money before its award is confirmed.

Another irritation is the need to keep accounts from different grants separate, even when the work being supported may be hard to distinguish. Under the simplified grant, only the requirement that the scope of the research or the principal investigator should not be changed are retained. Dr Thomas Walsh of the University of Florida at Gainesville estimates that principal investigators might save up to 15 per cent of their time under the new rules.

The five research agencies that have agreed to participate in the scheme are the National Institutes of Health, the Department of Energy, the Department of Agriculture, the National Science Foundation and the Office of Naval Research. Nine institutions of higher education in Florida have agreed to be guinea pigs. Enthusiasts hope that all federal research grants in universities will eventually be modelled on the new grant.

Tim Beardsley 